Ann. Biol. anim. Bioch. Biophys., 1979, 19 (6), 1669-1676.

\title{
Effect of thyroxine and thiourea on liver and muscle energy stores in the freshwater catfish, Heteropneustes fossillis.
}

par A. K. SINGH

\author{
Department of Zoology, Gorakhpur University
} Gorakhpur - 273001 , India

Summary. The hepato-somatic index (HSI) and the lipid, glycogen and protein contents of liver and muscle were studied in Heferopneusfes fossilis in response to various doses of thyroxine, thiourea, and thyroxine in combination with thiourea. These treatments did not change the $\mathrm{HSI}$ of $\mathrm{H}$. fossilis. A low dose $(5 \mu \mathrm{g} / \mathrm{fish})$ of thyroxine had no effect on the lipid content of liver and muscle or on the glycogen content of liver, but it increased liver and muscle protein contents significantly. Mid $(10 \mu \mathrm{g} /$ fish) and high $(50 \mu \mathrm{g} / \mathrm{fish})$ doses of thyroxine decreased the lipid and glycogen levels of the liver and the lipid content of muscle whereas the same doses did not alter liver and muscle proteins. All the tested doses of thyroxine, thiourea, and thyroxine in combination with thiourea did not affect the glycogen level of muscle. This experiment showed that thiourea treatment failed to alter the lipid and glycogen levels of tissues, but was very effective in depleting the protein content of liver and muscle. The influence of thyroxine in combination with thiourea on the lipid and glycogen content of liver and on muscle lipid was similar to that of thyroxine alone. Only a low dose of thyroxine with thiourea restored liver protein level. A high dose of thyroxine with thiourea did not check the decline of liver protein. Thiourea blockade in muscle was cancelled by both doses of thyroxine when administered along with thiourea, and the protein content restored was significantly higher than in the controls. The present findings demonstrate that the influence of thyroxine on body energy reserves (lipid, glycogen and protein) is tissue-specific and dose-dependent.

\section{Introduction.}

Thyroid regulation of metabolism in fish has been well documented (Gorbman, 1969). Investigations on the role of the thyroid hormone in lipid, glycogen, and protein regulation have yielded conflicting information. Increased abdominal fat content in rainbow trout (La Roche et al., 1963,1966) and liver lipid content in platyfish (BakerCohen, 1961) have been observed in response to radio-thyroidectomy. Narayansingh and Eales (1975b) have shown that thyroxine treatment lowered liver and visceral lipid in brook trout. On the other hand, an increase in muscle lipid was noticed after the injection of thyroxine in coho salmon (Higgs et al., 1976, 1977). Thyroxine hormone administration has also been reported to increase the hepatosomatic index 
(HSI) in hypophysectomized goldfish (Hurlburt, 1977). Thiourea has been seen to have varied effects in fish. Data analysis revealed that thiourea exerts inhibitory (Chambers, 1951, 1953) as well as stimulatory (Hopper, 1965) effects on liver lipid stores in Fundulus. Thiourea has already been demonstrated to depress both the synthesis and the release of thyroid hormone in different species of fish (Singh, 1970 ; Singh et al., 1977 ; Milne and Leatherland, 1978).

There is scant information regarding the influence of thyroxine on protein and glycogen content in fish. The intramuscular injection of thyroxine decreased muscle protein significantly in underyearling coho salmon (Higgs ef al., 1976), whereas it failed to bring about any change in yearling coho salmon (Higgs ef al., 1977). On the basis of in vitro experiments, Hochachka (1962) proposed the catabolic effect of thyroid on the carbohydrate reserves of brook trout.

The present study tried to determine the effect of administering thyroxine, thiourea, and thyroxine combined with thiourea on the HSI and on lipid, glycogen, and protein contents in the freshwater catfish, Heteropneustes fossilis.

\section{Materials and methods.}

Adult $H$. fossilis females having a mean weight of $45.5 \mathrm{~g}(41.5$ to $47 \mathrm{~g})$ and a mean length of $18 \mathrm{~cm}(16$ to $20 \mathrm{~cm}$ ) were collected from the Ramgarh Lake near Gorakhpur in october 1978, and were used in this experiment the same month. The fish were in post-spawning phase at that time (Sundararaj and Sehgal, 1970). They were fed macerated liver and dried shrimp throughout the experimental period. The temperature of the aquaria was not controlled, but the variation was similar in all the aquaria, ranging from 24 to $26^{\circ} \mathrm{C}$. The natural photoperiod was measured as $11.5 \mathrm{~L} / 12.5 \mathrm{D}$.

Thyroxine and thiourea administration.

L-thyroxine (Eltroxine, Glaxo, India) was dissolved in 0.6 p. $100 \mathrm{NaCl}$, and the control pH (0.6 p. $100 \mathrm{NaCl})$ and the thiourea solution were adjusted to 9 with $\mathrm{NaOH}$. Prior to the start for the experiment, the fish were divided into 7 groups. The individuals of these groups were injected with thyroxine, thiourea, or thyroxine combined with thiourea. The details of the treatment, doses and number of fish in each group are shown in tables 1 and 2 . The fish were injected daily at the same time between 3:00 and 3:30 p.m. to avoid a fluctuation in the lipid, glycogen and protein content due to the circadian rhythm of hormone administration (Meier and Burns, 1976). Before injection, the fish were lightly anesthetized (1:4000, MS 222); all the injections were given intraperitoneally unless otherwise noted. The volume of carrier liquid was always $0.2 \mathrm{ml}$.

\section{Tissue analysis.}

The fish were killed $24 \mathrm{hrs}$ after the last injection. The liver was dissected out and weighed to the nearest $\mathrm{mg}$ using a single pan electric balance (Mettler). The HSI (g liver weight $\times 100 / \mathrm{g}$ body weight) of individual fish was recorded. Each liver lobe was divided into two pieces. One piece was utilized for lipid estimation and the other 
for glycogen and protein estimation. A transverse slice of muscle was cut just behind the dorsal fin. This slice was divided into two equal halves by cutting it dorsoventrally. One lateral half was used for lipid estimation, whereas the other half was utilized for glycogen and protein estimation. Tissues samples were stored in deep-freeze until assayed. Lipid was estimated by the method of Folch et al. (1957). Details of the procedure have already been described (Singh and Singh, 1979). For glycogen and protein estimation, a weighed amount of tissue was homogenized in 10 p. 100 TCA (trichloroacetic acid). After centrifugation, the precipitate was washed with 5 p. 100 TCA. The supernatants obtained after centrifugation of the homogenate and washing of the precipitate were pooled for glycogen estimation. Glycogen was assayed by the procedure described by Dubois ef al. (1956). The precipitate was dissolved in $1 \mathrm{~N} \mathrm{NaOH}$, and the protein was estimated using the method of Lowry et al. (1951). Optical density of the color developed for the glycogen and the protein was measured at $490 \mathrm{~m} \mu$ and $600 \mathrm{~m} \mu$, respectively, by a Spekol spectrocolorimeter. The significance of difference between the two sets of observations was calculated by Student's t-test (Garret, 1966).

\section{Results.}

Treatments with a low $(5 \mu \mathrm{g} / \mathrm{fish})$, mid $(10 \mu \mathrm{g} / \mathrm{fish})$ or high $(50 \mu \mathrm{g} / \mathrm{fish})$ dose of thyroxine for 15 days did not change the HSI (table 1). Thyroxine at a low dose $(5 \mu \mathrm{g} /$ fish) did not affect liver and muscle lipid contents (batch 2, tables 1 and 2), whereas higher doses (10 and $50 \mu \mathrm{g} /$ fish) decreased the liver and muscle lipid significantly (batches 3, 4, tables 1 and 2 ). Thiourea alone $(50 \mu \mathrm{g} / \mathrm{fish})$ or in combination with a low dose of thyroxine ( $5 \mu \mathrm{g}$ thyroxine $+50 \mu \mathrm{g}$ thiourea/fish) failed to change the lipid levels of liver and muscle significantly (batches 5,6 , tables 1 and 2) when compared with the saline-treated controls. However, a higher dose of thyroxine with thiourea (10 $\mu \mathrm{g}$ thyroxine $+50 \mu \mathrm{g}$ thiourea/fish) was effective in bringing down liver and muscle lipid levels (batch 7, tables 1 and 2). All the tested doses of thyroxine (5,10 and $50 \mu \mathrm{g} / \mathrm{fish}$ ) lowered the liver glycogen (batches 2-4, table 1), but thiourea treatment was without effect (batch 5, table 1). Both the doses of thyroxine along with thiourea (5 or $10 \mu \mathrm{g}$ thyroxine $+50 \mu \mathrm{g} /$ fish) exerted I depressive effect on liver glycogen content similar to that recorded after treatment with the same doses of thyroxine alone (batches 6,7 , table 1). All the doses of thyroxine, thiourea, or thyroxine combined with thiourea failed to alter the muscle glycogen content (batches 2-7, table 2). An increase in liver and muscle protein was observed after the injection of $5 \mu \mathrm{g} /$ fish thyroxine for 15 days (batch 2, tables 1 and 2). However, there was no significant change in liver and muscle protein levels after the administration of a thyroxine dose level of 10 or $50 \mu \mathrm{g} /$ fish (batches 3, 4, tables 1 and 2). A very significant reduction in liver and muscle protein was observed in response to the injection of thiourea (batch 5, tables 1 and 2). Simultaneous injection of $5 \mu \mathrm{g}$ thyroxine $+50 \mu \mathrm{g}$ thiourea/fish restored the liver protein content to almost the level of the saline-treated controls (batch 6, table 1). A higher dose of thyroxine combined with thiourea (50 $\mathrm{g}$ thyroxine $+50 \mu \mathrm{g}$ thiourea/fish) did not prevent the decline of liver protein. Both the doses of thyroxine when administered along with thiourea ( 5 or $10 \mu \mathrm{g}$ thyroxine $+50 \mu \mathrm{g}$ thiourea/fish) increased the 


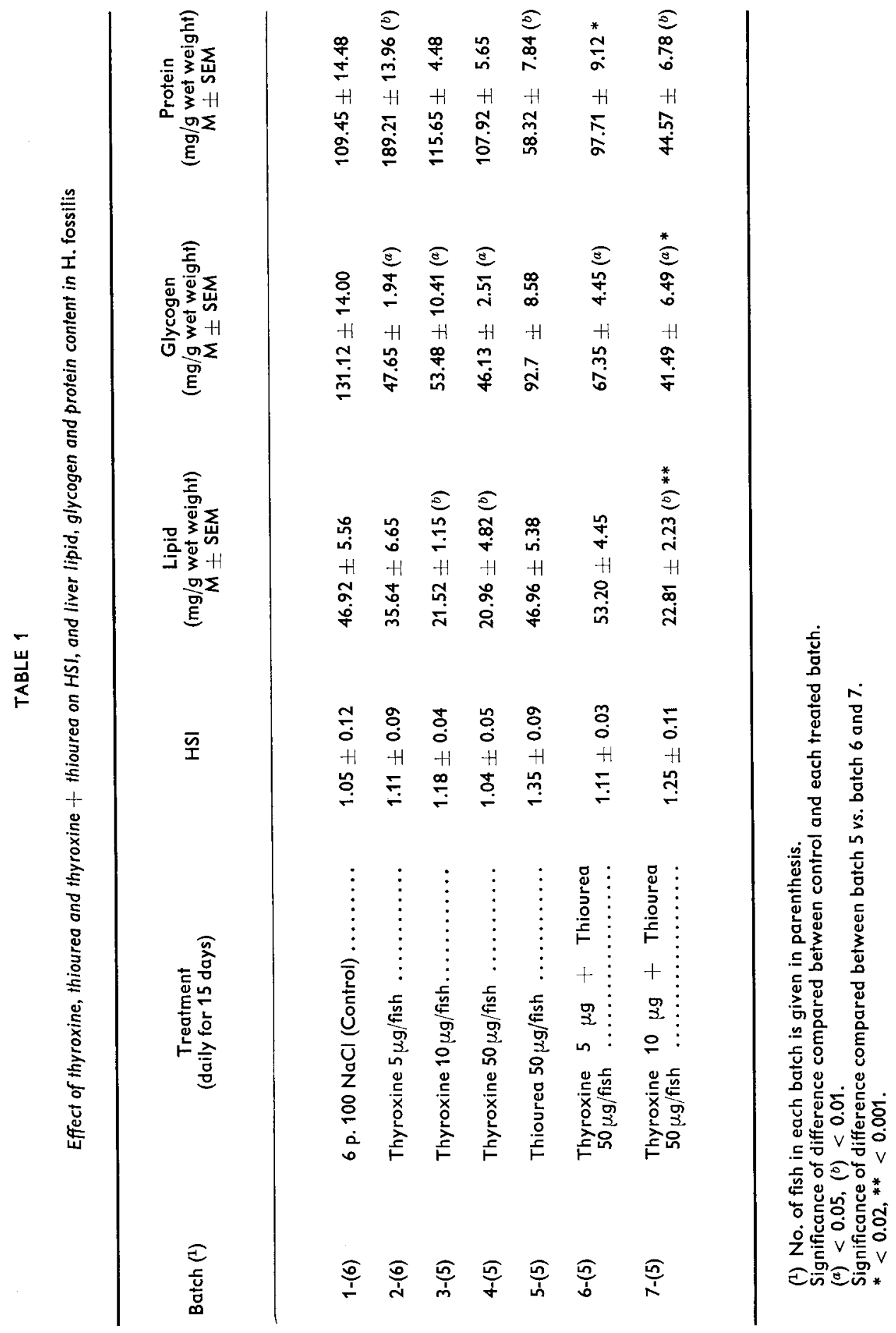


Fontaine et al. (1953) who have demonstrated a drecrease in liver glycogen after thyroxine administration.

Protein synthesis in the liver and muscle was augmented by the low dose $(5 \mu \mathrm{g} /$ fish) of thyroxine ; mid $(10 \mu \mathrm{g} /$ fish) and high $(50 \mu \mathrm{g} / \mathrm{fish})$ doses had no effect in this experiment. Endogenous thyroxine blocked by thiourea resulted in decreased levels of liver and muscle protein. In thiourea-blocked fish, only one dose in the liver and both the doses in muscle $(5 \mu \mathrm{g} /$ fish and $10 \mu \mathrm{g} /$ fish) restored the protein levels. Protein synthesis after thyroxine administration was observed in Solvelinus fontinalis by Narayansingh and Eales (1975a). A. dose-dependent response has been noted in the coho salmon, Oncorhynchus kisutch (Higgs et al., 1976 ; Higgs et al., 1977).

In the present experiment the HSI did not change in response to the various doses of thyroxine, thiourea, or thyroxine combined with thiourea. Contrary to this, several workers noted an increase in liver size after thyroxine (Takashima ef al., 1972 ; Hurlburt, 1978) and thiourea (Chambers, 1951, 1953) treatment, but thiourea treatment in carp decreased the liver size (Hatey, 1950). However, opinion is not unanimous concerning the mode of action by which the thyroid hormone affects liver size (Pickford, 1952, 1954 ; Pickford and Grant, 1968 ; Hopper and Yatvin, 1965).

It seems from the data on $\mathrm{H}$. fossilis that different doses of thyroxine have different effects on lipid, glycogen, and protein levels of liver and muscle. The metabolic influence of thyroxine also varies in different tissues (liver and muscle).

Reçu en mars 1979.

Accepté en avril 1979.

Acknowledgements. - I wish to thank Professor G. S. Shukla, Head, Zoology Department, Gorakhpur University, Gorakhpur for providing the necessary laboratory facilities. I am also grateful to Drs H. Friedli and M. Baggiolini of Sandoz Ltd., Switzerland for the generous supply of MS 222.

Résumé. On a étudié l'effet de doses variables de thyroxine, de thiourée et de thyroxine en combinaison avec la thiourée, sur l'index hépato-somatique et le contenu en lipides, glycogène et protéines du foie et du muscle chez Heteropneustes fossilis. Ces traitements n'affectent pas l'index hépato-somatique. Une faible dose $(5 \mu \mathrm{g} / a n i m a l)$ de thyroxine n'a pas d'effet sur le contenu en lipides du foie et du muscle ou en glycogène du foie, mais il augmente significativement les protéines du foie et du muscle. A moyenne (10 $\mu \mathrm{g} / \mathrm{animal})$ ef forte $(50 \mu \mathrm{g} / \mathrm{animal})$ doses la thyroxine diminue les niveaux de lipides et de glycogène du foie et le contenu lipidique du muscle, tandis que les mêmes doses n'altèrent pas les protéines du foie et du muscle. Aucune des doses de thyroxine, thiourée et thyroxine + thiourée utilisées n'affectent le niveau du glycogène dans le muscle. Le traitement par la thiourée ne modifie pas les niveaux de lipides et de glycogène des tissus, mais se montre très efficace pour diminuer le contenu protéinique du foie et du muscle. En ce qui concerne les lipides ef le glycogène du foie et les lipides du muscle, la thyroxine combinée à la thiourée a le même effet que la thyroxine seule. Une faible dose de thyroxine + thiourée rétablit le niveau protéinique du foie, mais à forte dose la chute des protéines du foie n'est pas arrêtée. Dans le muscle le blocage par la thiourée est annulé par toutes les doses de thyroxine administrée avec la thiourée : le contenu protéinique est alors significativement plus élevé que chez les animaux témoins. Ces résultats montrent que l'influence de la thyroxine sur les réserves énergétiques corporelles (lipides, glycogène, protéines) est spécifique suivant les tissus et dépend de la dose utilisée. 


\section{References}

BAKER-COHEN K. F., 1961. The role of thyroid in the development of platyfish. Zoologica, 46, 181222.

BARRINGTON E. J. W., BARRON N., PIGGINS D. J., 1961. The influence of thyroid powder and thyroxine upon the growth of rainbow trout (Salmo gairdneri). Gen. comp. Endocrinol., 1, 170-178.

CHAMBERS H. A., 1951. The effect of thiourea on male Fundulus heteroclitus. Anat. Rec., 109, 366.

CHAMBERS H. A., 1953. Toxic effects of thiourea on the liver of adult male killifish, Fundulus heteroclitus (Linn.). Bull. Bingham Oceangr. Coll., 14, 69-93.

DUBOIS M., GILLES K. A., HAMILTON J. K., REBERS P. A., SMITH F., 1956. Colorimetric method for determination of sugars and related substances. Anal. Chem., 28, 350-356.

FOLCH J., LEES M., SLOANE-STANLEY G. H., 1957. A simple method for isolation and purification of total lipid from animal tissues. J. biol. Chem., 226, 497-507.

FONTAINE M., BRADUC M. M., HATAY 3., 1953. Influence de la thyroxinisation sur la teneur en glycogène du foie des poissons téléostéens. C. R. Soc. Biol., 147, 214-216.

GARRET H. C., 1966. Statistics in psychology and education. Mc Kay Co. Inc., New-York, 15-161.

GORBMAN A., 1969. Thyroid function and its control in fish, 241-274. In HOAR W. S., RANDALL D. J., Fish Physiology, Vol. 2. Acad. Press, London.

HATEY J., 1950. Action de la thiourie sur le métabolisme glucidique de la carpe (Cyprinus carpio L.) C. R. Soc. Biol., 144, 955-957.

HIGGS D. A., DONALDSON E. M., DYE M. E., McBRIDE J. R., 1976. Influence of bovine growth hormone and L-thyroxine on growth, muscle composition and histological structure of the gonads, thyroid pancreas, and pituitary of coho salmon (Oncorhynchus kisutch). J. Fish. Res. Board Can., 33, 1585-1603.

HIGGS D. A., FAGERLUND U. H. M., Me BRIDE J. R., DYE H. M., DONALDSON E. M., 1977. Influence of combinations of bovine growth hormone, $17 \alpha$-methyltestosterone, and L-thyroxine on growth of yearling coho salmon (Oncorhynchus kisutch). Can. J. Zool., 55, 1048-1056.

HOCHACHKA P. W., 1962. Thyroidals effects on pathways for carbohydrate metabolism in a teleost. Gen. comp. Endocrinol., 2, 499-505.

HOPPER A. F., 1965. Inhibition of regeneration of the gonopodium of the guppy by treatment with thiouracil. J. Exp. Zool., 159, 231-240.

HOPPER A. F., YATVIN M. B., 1965. Protein metabolism in the liver of thiouracil treated goldfish. Growth., 29, 355-360.

HURLBURTH T. E., 1977. Role of thyroid gland in ovarian maturation of goldfish, Carassius auratus L. Can. J. Zool., 55, 1096-1913.

LA ROCHE G., WOODALL A. N., JOHNSON C. L., 1963. Effect of thyroidectomy on the development of rainbow trout (Salmo gairdneri, Rich). Endocrinology, 72, 840.

LA ROCHE G., WOODALL A. N., JOHNSON C. L., HALVER J. E., 1966. Thyroid function in rainbow trout (Salmo gairdneri Rich). II. Effect of thyroidectomy on the development of young fish. Gen. comp. Endocrinol., 7, 249-267.

LE RAY C., PICK P., BONNET B., VALLET F., 1969. Aspects comparés de l'activité thyroïdienne sur la physiologie de mugil auratus (Téléostéen, mugilidé) en croissance. Gen. comp. Endocrinol., 13, 517.

LOWRY O. H., ROSEBROUGH N. J., FARR A. L., RANDALL R. J., 1951. Protein measurement with the folin phenol reagent. J. biol. Chem., 193, 263-275.

MEIER A. H., BURNS T. J., 1976. Circadian hormone rhythms in lipid regulation. Amer. Zool., 16, 649-659.

MILNE R. S., LEATHERLAND J. F., 1978. Effect of ovine TSH, thiourea, ovine prolactin and bovine growth hormone on plasma thyroxine and tri-iodothyronine levels in Rainbow trout, Salmo gairdneri. J. comp. Physiol., 124, 105-110.

MURAT J., SERFATY A., 1970. Au sujet d'un effet hypoglycémiant de la thyroxine chez la carpe, Cyprinus carpio L. C. R. Soc. Biol., 164, 1842-1845. 
NARAYANSINGH T., EALES J. G., 1975a. Effects of thyroid Hormones on in vivo 1-14 C L-Leucine incorporation into plasma and tissue protein of brook trout (Salvelinus fontinalis) and rainbow trout (Salmo gairdneri). Comp. Biochem. Physiol., 52B, 399-405.

NARAYANSINGH T., EALES J. G., 1975b. The influence of physiological doses of thyroxine on the lipid reserves of starved and fed trout, Salvelinus fontinalis (Michill). Comp. Biochem. Physiol., 52B, 407-412.

PICKFORD G. E., 1952. Hormonal regulation of liver size in fish. Anat. Rec., 112, 429-430.

PICKFORD G. E., 1954. The response of hypophysectomized male killifish to prolonged treatment with small doses of thyrotropin. Endocrinology, 55, 589-592.

PICKFORD G. E., GRANT F. B., 1968. The response of hypophysectomized male killifish (Fundulus heferoclifus) to thyrotropin preparation and to bovine heterothyrotropic factor. Gen. comp. Endocrinol., 10, 1-7.

SINGH A. K., SINGH T. P., 1979. Seasonal fluctuation in lipid and cholesterol content of ovary, liver and blood serum in relation to annual sexual cycle in Heferopneustes fossilis (Bloch). Endocrinologie, 73, 47-57.

SINGH R., RAIZADADA R. B., SINGH T. P., 1977. Effects of some antithyroid drugs on the pituitarythyroid gonad axis in a freshwater catfish, Heteropneustes fossilis. Gen. comp. Endocrinol., 31, 451-456.

SINGH T. P., 1970. Thyroid function in fish. Indian Biologist, 2, 1-15.

SUNDARARAJ B. I., SEHGAL A., 1970. Short- and long-term effects of imposition of total darkness on the annual ovarian cycle of the catfish, Heteropneustes fossilis (Bloch). J. interdiscipl. Cycle Res., 1, 291-301.

TAKASHIMA F., HIBIYA T., PHAN-VAN NGAN, AIDA K., 1972. Endocrinological studies on lipid metabolism in rainbow trout. II. Effect of sex steroids, thyroid powder and adreno corticotrophin on plasma lipid content. Bull. Jap. Soc. Sci. Fish., 38, 43-49. 